\title{
Dimensi Pengetahuan Dan Tingkat Berpikir Pada Pembelajaran Kimia
}

\author{
Nopriawan Berkat Asi \\ Program Studi Pendidikan Kimia, FKIP, Universitas Palangka Raya, Indonesia \\ Email:nopriawanb@chem.upr.ac.id
}

\begin{abstract}
Abstrak :Pengetahuan yang dimaksudkan dalam kurikulum 2013 dapat dibedakan menjadi 4 (empat) dimensi pengetahuan. Dimensi pengetahuan meliputi pengetahuan faktual, pengetahuan konseptual, pengetahuan prosedural dan pengetahuan metakognitif. Tujuan penelitian ini untuk membahas dimensi pengetahuan dan tingkat berpikir pada pembelajaran kimia. Proses kognitif pada pembelajaran kimia di SMA diupayakan agar peserta didik mampu mencapai tingkat berpikir kritis dan mampu menyelesaikan soal-soal kimia yang memerlukan berpikir kritis. Peserta didik yang berpikir kritis dalam menyelesaikan soal-soa kimia adalah mereka yang dapat menerapkan pengetahuan prosedural dan pengetahuan metakognitif dalam penyelesaian soal kimia tertentu berdasarkan pada situasi tertentu yang disajikan kepadanya dengan tepat dan dapat menunjukkan kunci penyelesaian soal. Berpikir kritis merupakan kemampuan dasar untuk pengembangan pengetahuan dalam pembelajaran kimia. Peserta didik yang mendapatkan berbagai konsep dan konteks soal-soal kimia diharapkan dapat berhasil mengenali paradoks dan menyelesaikan soal-soal kimia dengan pengetahuannya.
\end{abstract}

\section{Kata kunci: Pengetahuan, Berpikir Kritis}

\section{Pendahuluan}

Pemerintah mengeluarkan kebijakan tentang Kurikulum 2013 yang diimplementasikan secara bertahap mulai tahun pelajaran 2013/2014. Kurikulum 2013 menerapkan pembelajaran berbasis aktivitas, yang diharapkan akan menghasilkan insan Indonesia yang produktif, kreatif, inovatif, dan afektif melalui penguatan sikap, pengetahuan, dan keterampilan yang terintegrasi (Kemendikbud, 2015). Pengetahuan merupakan salah satu ranah penilaian dalam pembelajaran. Pengetauhan dapat dipandang dari beberapa dimensi yang dibahas pada artikel ini.

Pengetahuan diperoleh melalui proses berpikir. Proses berpikir dimulai dari yang tingkat rendah sampai berpikir tingkat tinggi. Berpikir tingkat tinggi sering disamakan dengan berpikir kritis. Menurut Khincheloe (2000), berpikir kritis lebih dari sekedar berpikir tingkat tinggi. Menurut Anderson dan Krathwohl (2010), berpikir kritis berarti mampu secara efektif menggunakan keterampilan dalam pengambilan keputusan, secara khusus inti berpikir kritis adalah mengkritik. Pushkin (2000) mendefinisikan berpikir kritis dalam istilah mengembangkan kesadaran diri tentang pemikiran sendiri. Damarin (1993) mendefinisikan berpikir kritis dalam istilah pengetahuan paradoks. Forgarty dan 
McTighe (1993) mengatakan berpikir kritis mempunyai karakter yang serupa dengan memahami.

Masing-masing definisi dari berbagai sudut pandang memiliki keunikan tersendiri, tetapi ada kesamaan. Berpikir kritis melibatkan kontekstualisasi pengetahuan seseorang. Peserta didik perlu memahami dan menghargai pengetahuan

atau fakta yang memiliki konteks. Peserta didik membuat keputusan berdasarkan pengetahuan. Mereka belajar tentang diri sendiri melalui pengetahuannya sendiri. Mereka menyadari adanya situasi paradoks, mengakui adanya bias dan menghargai perbedaan pandangan antar individu karena pengetahuan mereka.

\section{Kajian Teori}

Secara teoritis perlu untuk menjelaskan arti pengetahuan dan berpikir kritis. Berpikir kritis dapat diartikan sebagai salah satu kebutuhan untuk menghargai bagaimana pemikiran berkaitan dengan pembelajaran dan pengetahuan itu sendiri. Dalam konteks proses belajar-mengajar pendidik mengajarkan pengetahuan yang pada dasarnya memberikan kesempatan kepada peserta didik untuk berpikir tentang pengetahuan tersebut. Pengetahuan adalah hasil dari proses berpikir peserta didik, yang menurut Krathwohl (2010) dapat berupa:

1. pengetahuan faktual

2. pengetahuan konseptual

3. pengetahuan prosedural

4. pengetahuan metakognitif

Pembahasan tentang hubungan antara tingkat berpikir dan dimensi pengetahuan memiliki hirarki paralel. Pengetahuan faktual adalah tingkat terendah pengetahuan dan sejajar dengan berpikir tingkat rendah. Pengetahuan faktual bersifat konkret. Pengetahuan prosedural sejajar dengan berpikir tingkat tinggi. Kombinasi pengetahuan prosedural dan metakognitif sejajar dengan berpikir kritis. Pengetahuan metakognitif bersifat abstrak.Pengetahuan faktual adalah mengetahui ada sesuatu yang terjadi, sedangkan pengetahuan prosedural adalah mengetahui cara melakukan sesuatu. Hal ini menunjukkan bahwa pengetahuan faktual adalah kumpulan fakta, teori, peristiwa, dan benda-benda, sedangkan pengetahuan prosedural melibatkan langkah-langkah dalam melakukan sesuatu.

Pertimbangkan hukum kekekalan massa yang menyatakan massa zat sebelum dan sesudah reaksi adalah sama. Agak sulit membedakan pengetahuan faktual, konseptual dan prosedural. Pengetahuan faktual merupakan pengetahuan dasar untuk menjelaskan, memahami dan secara sistematis menata suatu disiplin ilmu. Pengetahuan konseptual mencakup pengetahuan tentang kategori, klasifikasi dan hubungan antara dua atau lebih kategori atau klasifikasi. Pengtahuan prosedural adalah pengetahuan tentang cara melakukan sesatu. Pengetahuan 
faktual merupakan pengetahuan tingkat rendah, sedangkan pengetahuan prosedural merupakan pengetahuan tingkat tinggi.

Relatif mudah untuk membedakan berpikir tingkat rendah dan berpikir tingkat tinggi, tetapi tidak mudah untuk membedakan berpikir tingkat tinggi dan berpikir

kritis. Menurut Lewis dan Smith berpikir tingkat tinggi terjadi ketika seseorang mengambil informasi baru dan informasi disimpan dan dihubungkan dan/atau menata kembali serta memperluas informasi untuk mencapai tujuan atau kemungkinan jawaban terbaik dalam situasi yang membingungkan. Sejajar dengan pengetahuan prosedural, dengan kata lain, berpikir tingkat tinggi tidak selalu mengambil konteks "situasi membingungkan" atau memperhitungkan sesuatu yang tidak memerlukan berpikir kritis. Dalam penyelesaian soal kimia, peserta didik sering menjumpai persamaan matematika dan menurunkannya menjadi ungkapan baru terhadap penyelesaian soal multi langkah. Dalam penyelesaian soal kimia, peserta didik dapat menggabungkan pengetahuan mereka tentang rumus kimia, konversi mol-massa, dan persamaan reaksi kimia untuk menyelesaikan soal yang melibatkan stoikiometri.

Soal berikut sebagai ilustrasi untuk menjelaskan dimensi pengetahuan dan tingkat berpikir pada pembelajaran kimia:50ml Ammonium sulfat 0,5M ditambahkan ke dalam larutan berlebih Barium klorida. Campuran menghasilkan endapan.

1. Jika menghasilkan 3,25 gram endapan, berapa persen hasilnya (yield)?

2. Bagaimana kemungkinan hasil yang didapat berbeda jika menggunakan $50 \mathrm{ml}$ Perak nitrat 0,1M? Berikan alasan kuantitatif.

Sekilas, soal ini tampaknya menjadi masalah stoikiometri kompleks yang menggambarkan pemikiran tingkat tinggi. Namun, dengan melihat lebih dekat, soal ini menyajikan lebih dari sekedar hubungan molar dan konversi satuan. Sebagai contoh, peserta didik diberi larutan air sebagai reaktan, sehingga mereka harus memanfaatkan pengetahuan konseptual tentang molaritas. Selain itu, karena peserta didik melakukan perhitungan yang melibatkan endapan, mereka perlu untuk membedakan bahwa konversi molar melibatkan padatan yang berbeda dari konversi molar yang melibatkan larutan. Wilayah kognitif yang terabaikan ketika mengajar dan menilai pengetahuan peserta didik tentang stoikiometri adalah bahwa pendidik kimia terkadang tidak memberikan banyak waktu dalam mempelajari reaksi yang melibatkan larutan air atau gas. Hal ini dapat memberikan kesan bagi peserta didik bahwa masalah stoikiometri hanya melibatkan praktik berulang konversi mol-massa, mengabaikan konversi molaritas-mol dan konversi liter-mol. Dengan kata lain, pendidik kimia dapat bersalah karena menghadirkan konsep yang sangat rabun dari stoikiometri dan apa maknanya berkaitan dengan menganalisis reaksi kimia.

Selain itu, ada wilayah lain pengetahuan yang sering diabaikan oleh beberapa pendidik kimia selama penilaian pengetahuan, perhatikan bahwa rumus 
kimia reaktan tidak diberikan, tetapi nama-nama kimia. Hal yang tampaknya menjadi "seni yang hilang" adalah keterampilan menerjemahkan nama kimia menjadi rumus kimia dan sebaliknya. Lebih sering tes kimia dan buku soal pelajaran kimia, cenderung memberikan kedua nama kimia dan rumus kimia, sehingga mengambil kesempatan dari peserta didik untuk menunjukkan apa yang seharusnya menjadi keterampilan dasar mereka. Sekali lagi, hal itu mungkin memberikan kesan kepada peserta didik bahwa kimia hanyalah subjek memanipulasi angka untuk perhitungan daripada perhitungan yang hanya menjadi materi pelajaran. Selain itu, produk dari reaksi kimia tidak diberikan, memaksa peserta didik untuk menentukan produk dari reaktan tersebut yang merupakan reaksi substitusi ganda. Bahwa ada endapan terbentuk dan menuntut peserta didik untuk memprediksi produk endapan, berdasarkan aturan kelarutan. Sementara keterampilan ini mungkin tampak mendasar untuk pendidik kimia, pengetahuan tersebut sering diabaikan dalam penilaian peserta didik, sehingga membatasi pengetahuan mereka.

Mari kita lihat langkah-langkah penyelesaian soal, untuk menggambarkan hirarki dimensi pengetahuan dan tingkat berpikir. Pertama, peserta didik harus menulis persamaan kimia yang benar dan setimbang untuk reaksi Amonium sulfat dengan Barium klorida. Selain itu, peserta didik harus memprediksi produk berdasarkan makna reaksi subtitusi ganda, serta mengidentifikasi endapan.

$\left(\mathrm{NH}_{4}\right)_{2} \mathrm{SO}_{4(\mathrm{aq})}+\mathrm{BaCl}_{2(\mathrm{aq})} \rightarrow 2 \mathrm{NH}_{4} \mathrm{Cl}_{(\mathrm{aq})}+\mathrm{BaSO}_{4(\mathrm{~s})}$

Menulis persamaan kimia yang setimbang pada awalnya muncul gambaran pengetahuan faktual dan berpikir tingkat rendah. Namun, kita perlu menyadari bahwa ada pengetahuan prosedural dan berpikir tingkat tinggi yang terlibat juga. Peserta didik menggunakan keterampilan proses, misalnya bagaimana memprediksi produk dari reaktan berdasarkan jenis reaksi, cara menulis rumus kimia, dan bagaimana untuk menyetimbangkan persamaan. Semua keterampilan proses ini tampak algoritme. Lebih lanjut, memprediksi endapan adalah keterampilan proses dan membutuhkan lebih dari satu langkah berpikir, karena peserta didik perlu mengetahui produk mana yang larut dalam air dan mana yang tidak.

Peserta didik perlu mengetahui bahwa amonium sulfat adalah reagen pembatas dalam reaksi ini, dan bahwa semua perhitungan akan berhubungan dengan barium sulfat dan amonium sulfat. Sekali lagi, ini juga menggambarkan pengetahuan prosedural dan berpikir tingkat tinggi, yaitu mengidentifikasi hubungan kimia dan rasio molar yang melibatkan beberapa langkah pemikiran penyelesaian soal. Hal ini diikuti perhitungan yang menggambarkan pengetahuan prosedural dan berpikir tingkat tinggi, karena merupakan algoritme matematika yang diperlukan.
a) $\mathrm{mol}\left(\mathrm{NH}_{4}\right)_{2} \mathrm{SO}_{4}=(50 \mathrm{ml})(0,5 \mathrm{~mol} / \mathrm{L})\left(10^{-3} \mathrm{~L} / \mathrm{ml}\right)=0,025 \mathrm{~mol}$
b) sesuai teori, mol $\mathrm{BaSO}_{4}$ setara dengan $\mathrm{mol}\left(\mathrm{NH}_{4}\right)_{2} \mathrm{SO}_{4}=0,025 \mathrm{~mol}$
c) hasil teoritis $\mathrm{BaSO}_{4}=(0,025 \mathrm{~mol})(233,39 \mathrm{~g} / \mathrm{mol})=5,83 \mathrm{~g}$ 
d) persen hasil $=$ hasil aktual $/$ hasil teoritis $=3,25 \mathrm{~g} / 5,83 \mathrm{~g}=0,557=55,7 \%$

Namun, ada beberapa hal pengetahuan konseptual dan berpikir kritis yang terlibat, seperti peserta didik harus membuat keputusan penyelesaian soal berdasarkan konteks masalah. Sebagai contoh, peserta didik perlu tahu kapan harus menggunakan konversi mol yang melibatkan molaritas terhadap konversi mol ke gram. Proses perhitungan mol menggambarkan pengetahuan prosedural dan berpikir tingkat tinggi, yaitu penentuan yang perlu proses perhitungan dengan menggambarkan pengetahuan konseptual dan berpikir kritis.

Bagian kedua dari soal adalah contoh yang lebih ilustratif untuk berpikir kritis. Perak nitrat menggantikan Amonium sulfat, sehingga mengubah persamaan reaksi yang setimbang dan endapan yang terbentuk.

$2 \mathrm{AgNO}_{3(\mathrm{aq})}+\mathrm{BaCl}_{2(\mathrm{aq})} \rightarrow \mathrm{Ba}\left(\mathrm{NO}_{3}\right)_{2(\mathrm{aq})}+2 \mathrm{AgCl}_{(\mathrm{s})}$

Menulis rumus kimia, memprediksi produk dari reaksi, dan menyetimbangkan persamaan kimia menggambarkan pengetahuan prosedural dan berpikir tingkat tinggi. Namun, peserta didik menghadapi aturan kelarutan baru dibandingkan dengan reaksi pertama. Dalam reaksi baru ini, peserta didik menghadapi kasus Perak klorida sebagai endapan dan harus menyadari bahwa itu adalah salah satu dari beberapa klorida yang larut dalam air. Sementara peserta didik kemungkinan hanya tahu bahwa Perak klorida larut dalam air. Mereka perlu pengetahuan prosedural untuk membedakan antara aturan kelarutan untuk klorida dan senyawa nitrat.

Berpikir kritis terutama terletak pada paradoks peserta didik yang harus berurusan dengan menghitung hasil (yield) reaksi kedua.

a) $\mathrm{mol} \mathrm{AgNO}_{3}=(50 \mathrm{~mL})(0,1 \mathrm{~mol} / \mathrm{L})\left(10^{-3} \mathrm{~L} / \mathrm{mL}\right)=0,005 \mathrm{~mol}$

b) secara teoritis, $\mathrm{mol} \mathrm{AgCl}$ setara dengan $\mathrm{mol} \mathrm{AgNO}_{3}=0,005 \mathrm{~mol}$

c) hasil teoritis dari $\mathrm{AgCl}=(0,005 \mathrm{~mol})(143,45 \mathrm{~g} / \mathrm{mol})=0,72 \mathrm{~g}$

Seperti yang kita perhatikan, hasil teoritis untuk reaksi ini jauh lebih kecil dari 3,25 gram endapan dalam reaksi pertama. Apakah ada salah perhitungan? Tidak, perhitungan di atas benar mencerminkan data yang diberikan. Namun, hal ini menimbulkan pertanyaan yang menarik bagi peserta didik. Jika reaksi kedua hanya menghasilkan hasil teoritis 0,72 gram, haruskah 3,25 gram endapan didapat pada kondisi ini? Jawabannya jelas tidak, peserta didik tidak harus mendapat produk dari apa yang diprediksi secara teoritis.

Apakah soal bagian kedua akan membantu bagi peserta didik jika 50ml perak nitrat 0,5M yang digunakan? Belum tentu. Meskipun nilai molaritas dan volumenya tetap. Sementara perhitungan selanjutnya untuk hasil akan dianggap "realistis" (yaitu, hasil teoritis dari $\mathrm{AgCl}=3,59 \mathrm{~g}$, persen yield =90,6\%). Hasilnya tidak akan realistis dalam percobaan laboratorium, karena konsentrasi standar untuk larutan perak nitrat biasanya $0,1 \mathrm{M}$ bukan $0,5 \mathrm{M}$. Apakah senyawa kimia yang berbeda memiliki massa molar yang berbeda? Soal ini terlalu mendasar untuk mengharapkan peserta didik berpikir kritis. 
Suatu kontras yang ekstrim mungkin diperlukan untuk mendorong peserta didik agar berpikir diluar praktik perhitungan belaka dan menghadirkan paradoks kuantitatif untuk membantu merangsang pemahaman kualitatif. Sebagai contoh, peserta didik mungkin mengira bahwa di laboratorium beberapa larutan telah tersedia bagi mereka, dan beberapa peserta didik mungkin tidak tepat membaca label pada botol reagen, sementara mereka diinstruksikan untuk mempersiapkan reaksi pertama $\left(\mathrm{NH}_{4}\right)_{2} \mathrm{SO}_{4}+\mathrm{BaCl}_{2}$. Seorang peserta didik mungkin saja mencampur reagen untuk reaksi kedua $\left(\mathrm{AgNO}_{3}+\mathrm{BaCl}_{2}\right)$, mengamati endapan yang terbentuk dan memikirkan hal-hal yang mungkin salah dengan hasilnya, sementara peserta didik lain secara benar mencampur reagen untuk reaksi pertama. Semua peserta didik mengamati endapan yang terbentuk, tetapi beberapa peserta didik secara lebih signifikan daripada peserta didik yang lain.

Apa yang mungkin menjadi hal pertama dipikirkan peserta didik tentang tidak diperolehnya hasil perhitungan sebanyak endapan? Mungkin mereka tidak menggunakan cukup reagen? Kelebihan reaktan akan menghasilkan lebih banyak produk? Mungkin juga bahwa peserta didik menambahkan lebih banyak perak nitrat ke dalam gelas kimia sehingga mereka mengamati endapan lebih banyak? Ya, dan peserta didik tidak harus menyadari bahwa mereka keliru menambahkan terlalu banyak perak nitrat sesuai yang diperlukan dalam prosedur percobaan (perlu diingat bahwa perak nitrat bukan bahan kimia yang murah). Kesalahan tersebut dapat dan memang terjadi dalam praktik laboratorium kimia karena kurangnya pengalaman peserta didik menerapkan keterampilan menerjemahkan nama kimia dan rumus kimia, serta bagaimana reaksi kimia terjadi. Memang, ini adalah keterampilan yang relatif dasar dalam kimia, tetapi kurang dimanfaatkan dalam praktik kimia. Akibatnya, jika keterampilan tersebut tidak ditekankan atau diterapkan dalam kegiatan belajar dimasa depan, peserta didik akan melihat keterampilan ini sebagai hal sepele atau tidak relevan, daripada sebuah kerangka untuk pemahaman yang lengkap tentang reaksi kimia.

Pelajaran bagi peserta didik tidak hanya memperhatikan atau membaca label botol reagen, tetapi untuk berpikir tentang implikasi dari membaca label tersebut dan bagaimana reagen tertentu bereaksi satu dengan yang lain. Dalam kedua reaksi, endapan memang terbentuk, sehingga dari perspektif pengamtan, peserta didik akan melihat apa yang seharusnya mereka amati. Namun, dalam hal ini tidak berarti mereka berhasil melakukan reaksi atau belajar apa yang seharusnya mereka pelajari tentang reaksi presipitasi (pengendapan). Ini adalah hasil kuantitatif (yaitu, endapan yang mereka dapatkan) yang mengajarkan beberapa peserta didik bahwa ada sesuatu yang keliru dengan prosedur laboratorium mereka.

Alasan mengapa perlu menyajikan paradoks dalam soal kimia bukan sekedar untuk memperpanjang proses menghitung hasilnya atau berdasarkan data laboratorium, melainkan untuk menghadapkan peserta didik dengan skenario yang berbeda, sehingga mereka dapat membuat berbagai keputusan, dan belajar dari 
konsekuensi keputusan tersebut. Menurut Forgaty berurusan dengan paradoks merupakan contoh berpikir kreatif. Peserta didik mempertimbangkan analisis bias yang mencerminkan berpikir kritis. Paradoks adalah kontradiksi. Peserta didik disajikan sebuah skenario perak nitrat dan barium klorida bereaksi menghasilkan endapan, tetapi jauh lebih sedikit massanya daripada ketika Amonium sulfat bereaksi dengan barium klorida menghasilkan barium sulfat sebagai endapan. Dimana paradoksnya? Paradoks terletak pada pernyataan 3,25 gram endapan dibentuk ketika amonium sulfat bereaksi dengan barium klorida. Meskipun hal ini benar ketika barium sulfat mengendap, hal itu belum tentu benar ketika perak klorida dihasilkan sebagai endapan. Hal ini terjadi karena hasil teoritis untuk perak nitrat-barium klorida sangat rendah. Apakah peserta didik mengenali paradoks ini? Bagaimana peserta didik menanggapi hal itu?

Prediksi terletak pada pernyataan 3,25 gram endapan terbentuk ketika amonium sulfat bereaksi dengan barium klorida. Meskipun pada soal tidak secara eksplisit menyatakan bahwa 3,25 gram endapan barium sulfat, peserta didik harus menyimpulkan bahwa hasil ini sebenarnya hanya spesifik untuk produk ini, dan setiap hasil selanjutnya harus dilihat berdasarkan pada masing-masing reaksi. Berpikir kreatif melibatkan variabel bebas, berpikir kritis melibatkan pertimbangan terhadap implikasi dari variabel terikat.Selain menganalisis bias, Fogarty mempertimbangkan contoh berpikir kritis dalam hal membuat atribusi, perbandingan dan kontras, pengelompokkan, dan evaluasi. Apa artinya ini? Bagaimana aspek ini tercermin dalam soal ini terutama mengingat? Cara termudah untuk menjelaskan aspek-aspek ini adalah untuk menyajikan konsep kausalitas. Untuk sepenuhnya memahami soal kimia adalah menafsirkan makna/arti dari jawabannya. Jawaban berarti sesuatu ketika peserta didik dapat menyatakan bahwa peristiwa itu adalah karena sesuatu yang lain, dengan kata lain mengidentifikasi hubungan sebab-akibat antara variabel bebas dan variabel terikat. Berpikir kritis pada dasarnya membutuhkan beberapa aspek validasi jawaban, keputusan, dan evaluasi.

Pada setiap langkah analisis kuantitatif, peserta didik harus mengidentifikasi hubungan antara potongan informasi yang berbeda dan memvalidasi hubungan tersebut. Peserta didik disajikan beberapa tingkat paradoks dalam soal kimia, yang memerlukan keputusan yang berbeda dan hasil berdasarkan keputusan. Ini adalah sesuatu yang melibatkan pengetahuan prosedural, menggunakan strategi khusus, atau membuat keputusan tertentu berdasarkan langkah yang disajikan. Mungkin yang terbaik adalah untuk membahas berpikir kritis dalam hal peserta didik mengenali dan berurusan dengan pengetahuan prosedural.

\section{Pembahasan}

Ada hubungan antara berpikir kritis dan paradoks. Hal ini penting untuk menjelaskan implikasi dari paradoks tersebut. Dalam soal kimia yang disajikan 
pada bagian sebelumnya, kita mengamati peserta didik disajikan masalah stoikiometri yang relatif kompleks dengan menggabungkan beberapa aspek yang berbeda dari pengetahuan faktual dan pengetahuan prosedural (misalnya, rumus kimia, menyeimbangkan persamaan kimia, massa molar, konversi mol, reagen pembatas, aturan kelarutan). Jika pendidik kimia hanya ingin mengkonfirmasi bahwa peserta didik dapat menggabungkan beberapa tingkat pengetahuan untuk memecahkan masalah, maka skenario amonium sulfat bereaksi dengan barium klorida sudah cukup. Namun, hal itu belum cukup jika tujuannya adalah sampai tingkat berpikir kritis.

Struktur masalah pengetahuan yang disajikan sangat penting dan perlu merefleksikan tujuan pembelajaran yang dimaksudkan. Terlepas dari tujuan pembelajaran berpikir tingkat tinggi ataupun berpikir kritis, masalah kimia yang terstruktur dengan baik memberikan kepada peserta didik kesempatan untuk meninjau pengetahuan prasyarat dan memastikan pengetahuan domain mereka terorganisir dengan baik. Jika tujuan pembelajaran yang dimaksud adalah berpikir kritis, maka masalah kimia yang disajikan perlu menghadirkan kepada peserta didik altematif skenario terhadap cara berpikir yang mereka biasa gunakan. Hal ini tidak memadai dengan membatasi ruang lingkup pengetahuan peserta didik dengan membatasi konsep, seperti halnya satu atau dua aturan kelarutan yang sama, reagen pembatas yang sama, atau urutan yang sama dari langkah-langkah prosedural. Apakah instruksi yang berulang-ulang akan efektif, sehingga mengakibatkan penguasaan dalam lingkup pengetahuan dan keterampilan yang terbatas? Meskipun hal ini mungkin mengindikasikan kemampuan berpikir yang tinggi dalam beberapa aspek ilmu pengetahuan, tetapi tidak selalu menerjemahkan keterampilan ilmiah.

Ada persamaan antara pandangan pemikiran kritis dalam hal pengambilan keputusan dan berpikir evaluatif dan apa yang sebut sebagai pengembangan keterampilan validasi dan regulasi kognisi. Untuk membuat keputusan atau evaluasi "valid", peserta didik perlu membuat hubungan antara skenario tertentu dan/atau data dan hasilnya. Peserta didik perlu memvalidasi keputusan atau melakukan evaluasi yang tidak berbeda dari proses pemeriksaan mendasar untuk jawaban mereka dalam latihan aljabar. Apa dasar menjawab pertanyaanpertanyaan: Apakah jawabannya masuk akal? Mengapa ya atau mengapa tidak? Bagaimana?

Jawaban itu sendiri pada dasarnya berarti tanpa hubungan ke soal. Soal memiliki konteks sendiri; begitu juga dengan solusi atau jawaban. Peserta didik dapat sampai pada kesimpulan yang benar, atau menjawab dengan alasan yang tepat atau salah.

Apa yang menghubungkan segala sesuatu bersama-sama adalah proses pemecahan masalah. Bagi kita sebagai pendidik ilmu untuk menentukan sejauh mana peserta didik mengembangkan keterampilan berpikir kritis, kita perlu mengamati bagaimana mereka memecahkan masalah. Selain mengkonfirmasikan 
pengetahuan prasyarat dan organisasi pengetahuan domain, kita perlu menyajikan pelajar situasi paradoks dalam soal. Penting untuk mengamati sejauh mana peserta didik mengenali paradoks dan bagaimana mereka berurusan dengannya. Dengan kata lain, kita perlu mengamati sejauh mana pengetahuan konseptual dan prosedural peserta didik, atau lebih secara khusus, hubungan antara pengetahuan konseptual dan prosedural mereka.

Kita bisa menyebut hubungan ini sebagai regulasi kognisi. Secara umum, hubungan ini dapat memberitahu kita tentang bagaimana berbagai pengetahuan dan tingkat berpikir peserta didik. Sekali lagi, ini memerlukan masalah ilmu untuk menyajikan beberapa tingkat paradoks untuk peserta didik. Masalah rutin kurang paradoks hanya memungkinkan peserta didik menggunakan pengetahuan apriori untuk mengkonfirmasi kebenaran. Unsur paradoks memungkinkan pendidik dan peserta didik untuk memperluas ruang lingkup pengetahuan yang bisa diterapkan dalam masalah, sehingga meningkatkan kebermaknaan pengetahuan peserta didik dan validitas atau nilai jawaban mereka.

Hal ini penting untuk menghargai bahwa membangun masalah yang lebih kompleks dalam kegiatan belajar, tidak selalu menyamakan advokasi berpikir kritis. Beberapa pendidik dapat mempertimbangkan ilustrasi berpikir kritis mungkin hanya benar-benar mencerminkan berpikir tingkat tinggi. Mengapa? Karena kompleksitas dari kegiatan belajar mungkin hanya menunjukkan jumlah kuantitatif pengetahuan peserta didik yang dituntut untuk dimiliki atau digunakan. Dengan kata lain, kita hanya berurusan dengan volume terbatas pengetahuan yang tidak cukup berusaha untuk menjawab pertanyaan-pertanyaan: Apa yang peserta didik tahu? Berapa banyak pengetahuan yang peserta didik miliki?

Di sisi lain, ketika kegiatan belajar, terlepas dari kompleksitas peserta didik, situasi paradoks tidak hanya dapat lebih baik menjawab pertanyaanpertanyaan tersebut. kita mungkin bisa menjawab pertanyaan-pertanyaan: Bagaimana peserta didik: tahu apa yang mereka ketahui? Mengapa mereka tahu apa yang mereka ketahui? Bagaimana mereka menerapkan apa yang mereka tahu? Kita berhadapan dengan spektrum yang lebih luas dari pengetahuan, kontekstual pengetahuan, baik secara kuantitatif dan kualitatif.

Berpikir kritis perlu memiliki tempat yang lebih menonjol dan lebih baik didefinisikan dalam pendidikan sains. Pengetahuan harus dibangun dalam hal kedalaman dan luasnya. Berpikir kebutuhan untuk menjadi lebih dari pada tingkat linear; itu harus luas, terletak, dan saling berhubungan. Peserta didik tidak hanya perlu menghargai apa pengetahuan itu, tetapi bagaimana mereka menggunakannya. Kapan dan di mana mereka menggunakannya, dan mengapa mereka menggunakannya. Literasi sains harus berarti lebih dari sekedar kepemilikan volume pengetahuan; kepemilikan memiliki sedikit nilai jika tidak digunakan untuk aplikasi secara maksimal. 
Jurnal Ilmiah Kanderang Tingang 9(2) (2018) 103-113

ISSN 2087-166X

Juli-Desember 2018
Fakultas Keguruan dan Ilmu Pendidikan

Universitas Palangka Raya

Email:info@chem.upr.ac.id Web:www.chem-upr.education/ojs

\section{Kesimpulan}

Dimensi pengetahuan meliputi pengetahuan faktual, konseptual, prosedural dan metakognitif. Pengetahuan faktual bersifat konkret dan sejajar dengan bepikir tingkat rendah. Pengetahuan prosedural sejajar dengan berpikir tingkat tinggi. Pengetahuan metakognitif bersifat abstrak yang merupakan strategi kognitif. Kombinasi pengetahuan prosedural dan metakognitif sejajar dengan berpikir kritis. Berpikir kritis merupakan mode kognisi yang melibatkan hubungan antara pengetahuan prosedural dan metakognitif. Hal ini terutama terkait dengan penyelesaian masalah dalam soal kimia kuantitatif dalam pembelajaran kimia. Kontekstualisasi kognisi mencerminkan penggunaan pengetahuan metakognitif peserta didik yang berkaitan dengan situasi yang khusus. Aspek kunci untuk hubungan ini adalah adanya paradoks. Situasi paradoks menciptakan peluang yang menantang peserta didik untuk belajar mengenali karakteristik unik dari soal kimia, karakteristik yang menentukan mana konsep yang secara khusus relevan untuk menyelesaikan soal. Inti berpikir kritis adalah kemampuan untuk mengenali situasi paradoks dalam soal, membuat keputusan berdasarkan paradoks, dan menjelaskan implikasi dari paradoks. Tanpa unsur paradoks, pendidik kimia tidak memberikan kesempatan yang cukup kepada peserta didik untuk mengembangkan keterampilan berpikir kritis. Unsur paradoks adalah penting jika pendidik yang benar-benar ingin memahami tingkat berpikir peserta didik dalam memahami konsep-konsep sains dan konteks yang tepat dan aplikatif.

\section{Daftar Rujukan}

Anderson, L.W. \& Krathwhol, D.R. (2010). Kerangka landasan pembelajaran, pengajaran dan asesmen. Judul asli: a taxonomy for learning, teaching and assessing: a revision of Bloom's taxonomy of educational objectives. Penerjemah: Agung Prihantoro. Pustaka Pelajar.

Damarin, S.K. (1993). Schooling and situated knowledge: Travel or tourism?. Educational Technology.

Forgarty, R. \& McTighe, J. (1993). Educating teachers for higher order thinking: The three-story intellect. Theory into Practice.

Gagne E.D., Walker Yekovich. C., \& Yekovich. F.R. (1993). The cognitive psychology of school learning, $2^{\text {nd }}$ edition. HarperCollins, New York.

Direktorat Jenderal Pendidikan Dasar dan Menengah. (2015). Panduan Penilaian untuk Sekolah Menengah Atas. Kementerian Pendidikan dan Kebudayaan.

Kincheloe, J.L. (2000). Making Critical Thinking Critical. dalam D. Weil \& H.K. Anderson. Perspectives in critical thinking: essays by teachers in theory and practice, Peter Lang, New York. 
Jurnal Ilmiah Kanderang Tingang 9(2) (2018) 103-113

ISSN $2087-166 \mathrm{X}$

Juli-Desember 2018
Fakultas Keguruan dan Ilmu Pendidikan

Universitas Palangka Raya

Email:info@chem.upr.ac.id Web:www.chem-upr.education/ojs

Lewis, A. \& Smith, D. (1993). Defining higher order thinking. Theory into practice.

Pushkin, D.B. (2000). Critical thinking in science - How do we recognize it? Do we foster it? dalam D. Weil \& H.K Anderson. Perspectives in critical thinking: essays by teachers in theory and practice, Peter Lang. New York. 